\title{
The enterprise culture heritage of Minangkabau cuisine, West Sumatra of Indonesia as a source of sustainable competitive advantage
}

\author{
Annisa Mardatillahi
}

\begin{abstract}
The enterprise cultural heritage of the Minangkabau cuisine, West Sumatra in Indonesia was formed by several factors such as history, knowledge, and inheritance of processing procedures to the presentation of cuisine. Minangkabau cuisine has a wealth of assets in the form of heterogeneity of culinary heritage resources that are thick with a unique value of a unique taste. Thus, Minangkabau cuisine with its cultural heritage becomes the strength of cultural identity for the Minangkabau people in the process of selecting food. The sustainability of the Minangkabau restaurant business cannot be separated from the ownership of its valuable, scarce, inimitable, and non-substitute resource assets so that it is not easy to move to competitors. The findings in this study have never been answered in previous literature reviews; furthermore, this paper is able to explain treasures about the history, geographical, cultural, and social significance of ethnic food Minangkabau with scientific evidence, the enterprise culture heritage in achieving the sustainable competitive advantage of Minangkabau cuisine with a more interesting scientific approach. This review aims to explain scientifically the identity of food and culture from Minangkabau cuisine, West Sumatra, Indonesia, namely reviewing the history and food culture of Minangkabau cuisine related to its origin, the authenticity of Minangkabau food, and the enterprise cultural heritage as a restaurant for Minangkabau cultural cuisine as a source of sustainable competition in this global business era. In the end, it was found that Minangkabau cuisine has high heterogeneity resource assets as a source of achievement of sustainable competitive advantage by heritage value.
\end{abstract}

Keywords: Regional cuisine, Enterprise cultural heritage, Food cultural, Minangkabau ethnic food, West Sumatra

\section{Introduction}

The issue of the sustainability of traditional food businesses in the era of globalization has been increasingly discussed over the last few decades. This is a great issue interesting to discuss because traditional food is a cultural heritage of food that is passed down from generation to generation as a symbol of the culture of a particular community that functions to unite cultural identity because of the same ownership [1-3]. Traditional food as a cultural heritage of the past has a higher

Correspondence: annisa.fisipol@soc.uir.ac.id

Universitas Islam Riau, Pekanbaru, Riau, Indonesia value because of the history which until now answers the consumer's saturation towards the homogeneity of globalization [4-7]

The sustainability of traditional food businesses in the current era of globalization requires creative and innovative thinking based on valuable resources that are not owned by newcomers such as past history and knowledge [8]. Asset resources owned in the traditional food business sector have a higher value due to their uniqueness but unfortunately this has not been exploited more deeply [9]. The unique value contained in traditional food is preferred by many consumers compared to

(c) The Author(s). 2020 Open Access This article is licensed under a Creative Commons Attribution 4.0 International License, which permits use, sharing, adaptation, distribution and reproduction in any medium or format, as long as you give

appropriate credit to the original author(s) and the source, provide a link to the Creative Commons licence, and indicate if changes were made. The images or other third party material in this article are included in the article's Creative Commons licence, unless indicated otherwise in a credit line to the material. If material is not included in the article's Creative Commons licence and your intended use is not permitted by statutory regulation or exceeds the permitted use, you will need to obtain permission directly from the copyright holder. To view a copy of this licence, visit http://creativecommons.org/licenses/by/4.0/. 
conventional food because its authenticity can be reminiscent of a past memory [10].

Memories from the past valuable in traditional foods are also shared by traditional food of Minangkabau, West Sumatra, Indonesia. The name Minangkabau comes from the words Minang and Kabau which are famous in the Tambo legend [11]. Minangkabau cuisine is one of Indonesia's food cultures that come from the nature, history, and diversity of Indonesian culture, rich in taste and variety [12]. They are indigenous people of the highlands of West Sumatra in Indonesia. The matrilineal clan is inherited from a female lineage. For religious matters, Minangkabau has a very strong background of Islamic influence, although it still follows the traditions influenced by animist beliefs before Islam entered the realm of Minang. The Islamic background and culture of Minangkabau ethnic have an influence on their food culture, starting from the selection of raw materials, preparation to presentation.

The food culture of an ethnic group comes from the accumulation of local culture which is the authenticity legacy of the previous generation [13]. Food culture is formed from the habits of indigenous people about the food choices they eat because the cultural identity of the community is seen from their food choices including from the preparation of choosing raw materials, processing to presentation; this is all influenced by the beliefs, values, and social norms of the community [14]. The food culture of ethnic community groups is determined by personal, religious, and ethnic complexity ultimately determining food choices that reflect values and habits [15]. Likewise, the ethnic food culture of the Minangkabau originating from the culinary heritage of the past is strongly influenced by the culinary culture of the Middle East and India together with the entry of Hinduism, Buddhism, and Islam. The Minangkabau has a Muslim background; this greatly influences the daily process of food culture to prioritize halal.

The Minangkabau ethnic group has a matrilineal lineage is the most in the world [16]. Although the Minangkabau clan came from a female lineage in terms of food culture at the preparatory stage, it still involved men, resulting in elaboration between women and men, especially in the preparation of foods derived from animal protein for special events such as religious days and customary events. Even in Padang restaurant, the head chef is always male and his servants are male [17].

Minangkabau cuisine is known as ethnic foods that are rich in savory and spicy flavors using raw materials from local resources and processed using local knowledge handed down from previous generations. This is in line with the thinking of [18] ethnic food which is food that comes from local resources and local knowledge of indigenous people in producing these foods. Many
Minangkabau dishes use animal protein such as local beef and local vegetables such as sweet potato shoots and fern vegetables. The savory and spicy taste of Minangkabau cuisine is obtained from coconut milk and red chili which are consumed by many Minang people. Thick coconut milk used in Minang cuisine is obtained from the results of the original coconut of West Sumatra which is famous for having the best quality because it is thick and savory its greatly influences the taste of authenticity of Minangkabau cuisine which uses coconut milk a lot.

Minangkabau cuisine delivers from the Minangkabau cultural ethnic group which adheres to the matrilineal kinship line, West Sumatra, Indonesia. Minangkabau cuisine is easily known and popular found through Padang restaurants. The name of this restaurant is taken from the name of the city of Padang, which is the capital of the province of origin of the Minangkabau people, West Sumatra. Possessing the taste of spicy and meat-based dishes, Padang restaurant is famous as an element of Indonesian culture that is never overlooked [19] (Fig. 1).

The rich culinary tradition owned by the Minangkabau cultural ethnic is known for its savory and spicy taste. The savory and spicy taste is obtained from coconut milk and red chili which are consumed by many Minang people. In Indonesia, Minangkabau cuisine is spread almost in most parts of Indonesia; this is evidenced by the emergence of many Minangkabau restaurant businesses in the region. Even in some foreign countries such as those in Asia, Europe, and America, Minangkabau restaurants can also be found because this savory and spicy taste of Minangkabau food can be accepted by the tastes of consumers in general.

Previous literature reviews reveal more about cooking Minangkabau food which consists of various types of Minangkabau cuisine and how to process it. Nevertheless, as earlier literature was not found about how the food culture of Minangkabau cuisine became a culinary heritage which became the power to appear more valuable and unique as a source of sustainable competitive advantage. Therefore, this paper reviews scientific literature that focuses and presents the cultural heritage of Minangkabau cuisine enterprise (Figs. 2, 3, 4, 5, 6, and 7).

The contribution of this paper is expected to contribute treasures about the history, geographical, cultural, and social significance of ethnic food Minangkabau with scientific evidence. This paper aims to introduce and explain scientifically the food and culture identity of Minangkabau cuisine, West Sumatra, Indonesia, which is arranged in order as follows reviewing the history of Minangkabau cuisine related to its origin, authenticity of Minangkabau food, and culture heritage enterprise Minangkabau cuisine restaurant as a source of sustainable competitive advantage in this global business era. At the 


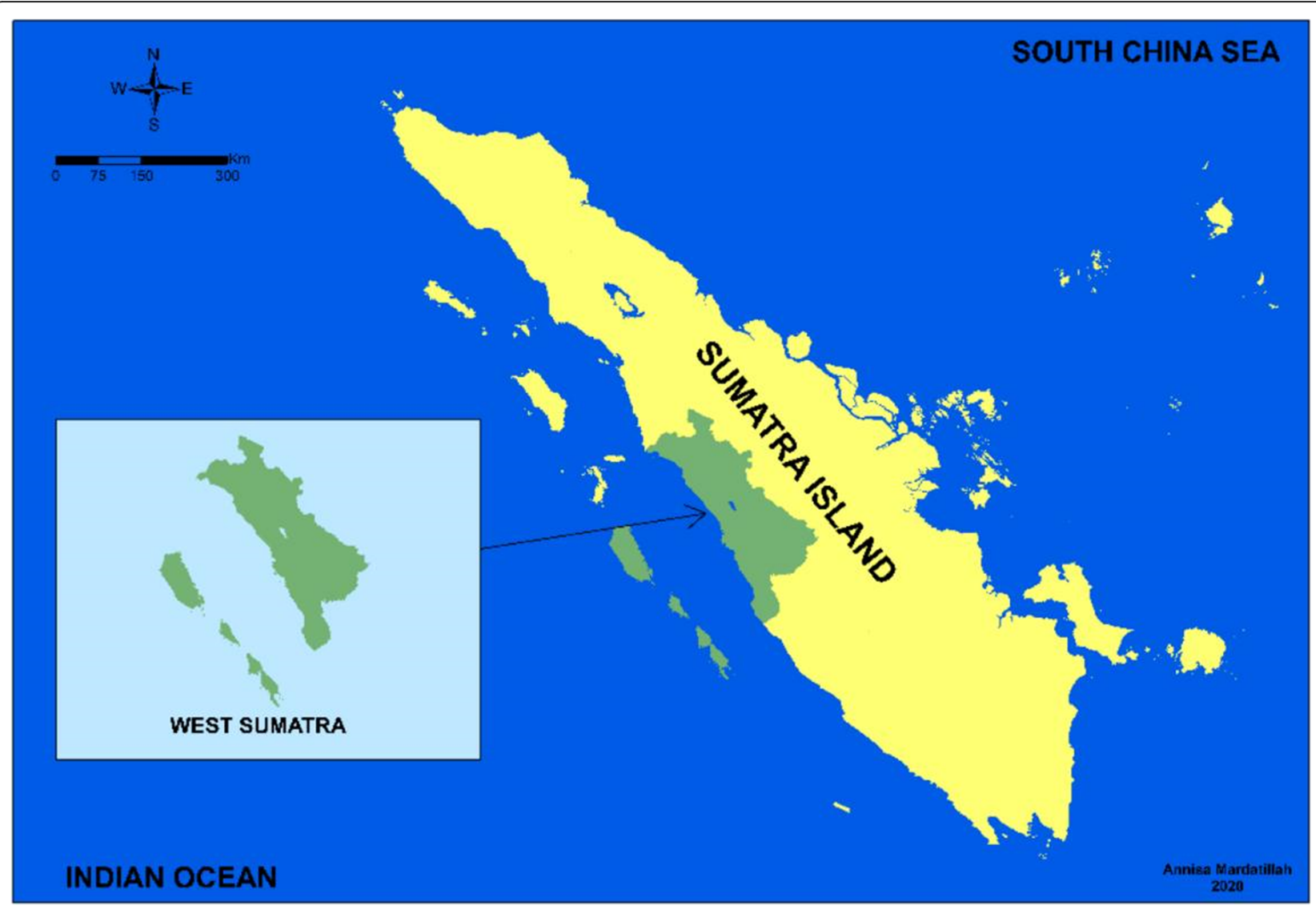

Fig. 1 Map of West Sumatra. Indonesia is the largest archipelago in the world with tens of thousands of islands; there are 5 largest islands in Indonesia. Sumatra island is one of the largest islands in Indonesia. West Sumatra is located on the west coast of the island of Sumatra, Indonesia, which consists of lowlands on the west coast and volcanic plateaus formed by Bukit Barisan. Source: made by Annisa Mardatillah, 2020

end, a variety of Minangkabau cuisine and its characteristics will be presented.

\section{History and authenticity of Minangkabau cuisine}

The Minangkabau is an indigenous tribe in the West $\mathrm{Su}$ matra region, Indonesia. West Sumatra region in the sixteenth century became one of the trade routes of traders from the Middle East and India [20]. The arrival of Indians to the west coast of Sumatra since the thirteenth century not only trades but also transmits the culture of eating habits which causes cultural acculturation by strengthening the availability of spices in the West Sumatra region; its cuisine in the West Sumatra region is much influenced from India, one of only from the use of coconut milk and spices [20]. One of the famous Minangkabau dishes, rendang, is strongly influenced by Indian culture; the use of spices such as cardamom, coriander, onion and garlic, ginger, turmeric, galangal, and red chili influenced from a mixture of Indian culinary spices [21].

Minangkabau cuisine is better known today as Padang cuisine. Minangkabau cuisine is a culinary heritage that is rich in Minangkabau culture. Minangkabau came from the Deutro Malay group (the young Malay). They migrated from parts of mainland Asia about 500 years BC. The spread of Deutro Malay ancestors is estimated from Asia, towards Thailand, then into West Malaysia and continue into places in the archipelago. Minangkabau nature was once inhabited by nations that came from Arabia, Persia, and India even before the input of Islam. In addition, the Minangkabau region has the availability of natural resources rich in spices such as pepper and nutmeg. The phenomenon of food development is very dynamic in the world of multiculturalism [22]. This also happens to the development of Minangkabau customs and culture that continues to spread as a result of social interactions that move dynamically so that it becomes a culinary cultural heritage. However, the demand for the authenticity of traditional food is still always expected by consumers through local processing, and the skill of serving food locally shows commitment in maintaining cultural traditions and forms of appreciation expressed as cultural heritage $[14,15,23-25]$. 

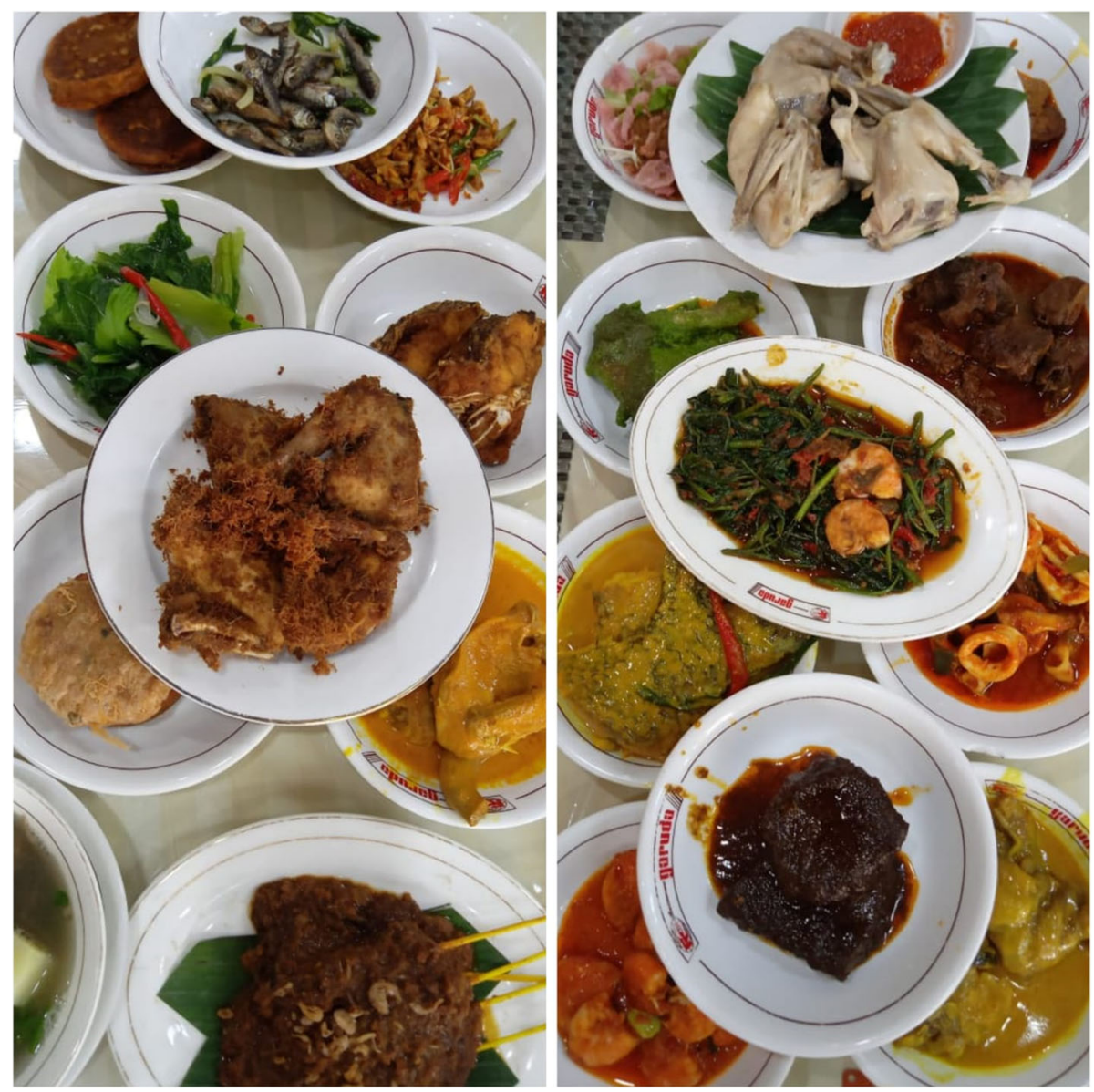

Fig. 2 Various types of Minangkabau cuisine. Minangkabau cuisine is usually served for daily cuisine and religious and customary holidays. This dish is served by serving at Padang restaurant, and customers can choose the type of cuisine they want to eat. Source: Author Documentation, 2020. It was taken on March 5, 2020

The authenticity of Minangkabau cuisine as a cultural heritage of food is ethnic food that has characteristics compared to other regions. This is in line with [18] that ethnic food that is processed from local resources available in a particular local area with the ability of local knowledge in its processing. As it is in the context of the authenticity of Minangkabau cuisine, it is known for its savory and spicy taste. This savory and spicy taste is obtained from coconut milk and red chili which dominate Minangkabau's spices and mixed with various kinds of spices. Raw materials in Minangkabau cuisine consist of animal, fish, and plant products such as beef, duck, chicken, sea fish, and vegetables which use cassava leaves, jackfruit, long beans, and beans. The hallmark of Minang people in processing Minangkabau cuisine is to prioritize the composition of seasoning which is blended with ingredients and condiments that are thick and thick. The spices used come from Indonesian soil so that the resulting flavor becomes more familiar to the tongue of the general public.
The savory and spicy taste of Minangkabau cuisine is inseparable from the spices contained in this cuisine, such as coconut milk, characteristic of Minangkabau cuisine that is savory, sticky, and thick derived from biological natural resources. The Minang people believe in the extraordinary taste of cuisine because it uses coconut milk in its food processing. Red chili is believed to provide a spicy taste that can warm the body. In addition, red chili contains antioxidants and multivitamins which are good for counteracting free radicals from animal raw materials commonly used in desert cooking; ginger, turmeric, galangal, and lemongrass are the main spices that are common in Minangkabau dishes other than shallots and garlic. Furthermore, the fragrant aroma of Minangkabau cuisine comes from turmeric leaves, orange leaves, and bay leaves.

Minangkabau cuisine processing methods consist of several types are burned, such as grilled fish, grilled chicken, and satay Minangkabau; cooking boiled with red chili without coconut milk such as asam padeh fish 


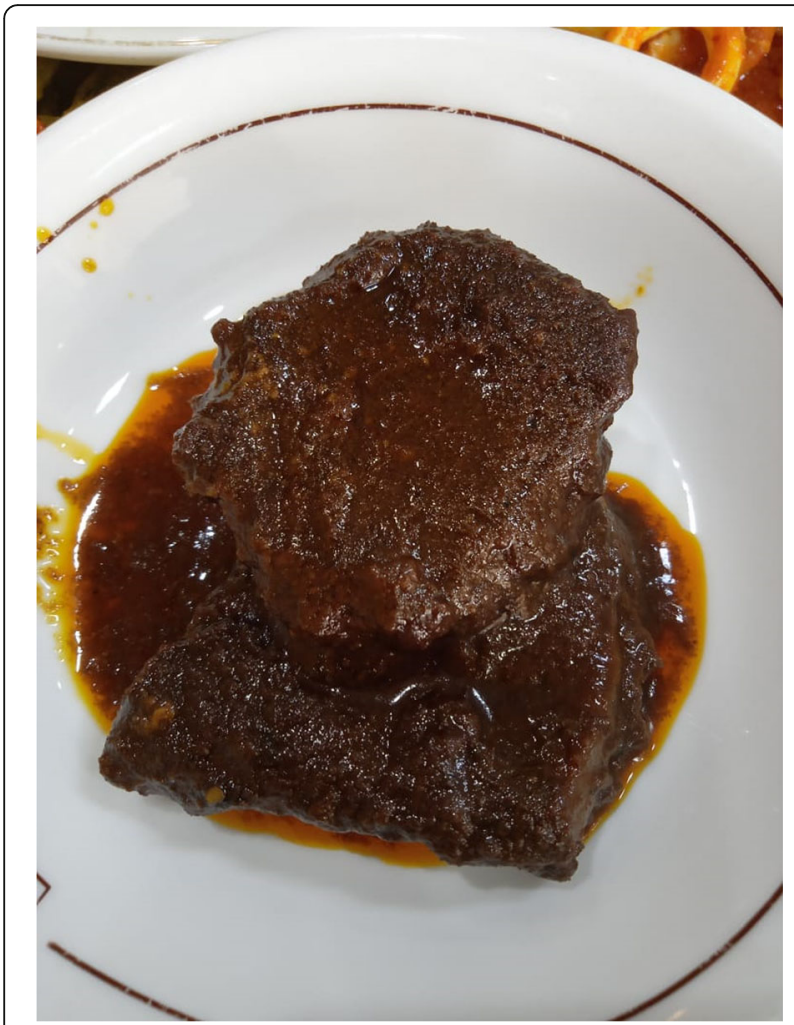

Fig. 3 Rendang. Rendang is made from a mixture of spices and coconut milk. Usually use onions, garlic, turmeric, ginger, galangal, cardamom, cinnamon, cumin, chili, and thick coconut milk. The protein used is beef, buffalo meat, chicken, and eel. Cook over the furnace for 5 to $6 \mathrm{~h}$

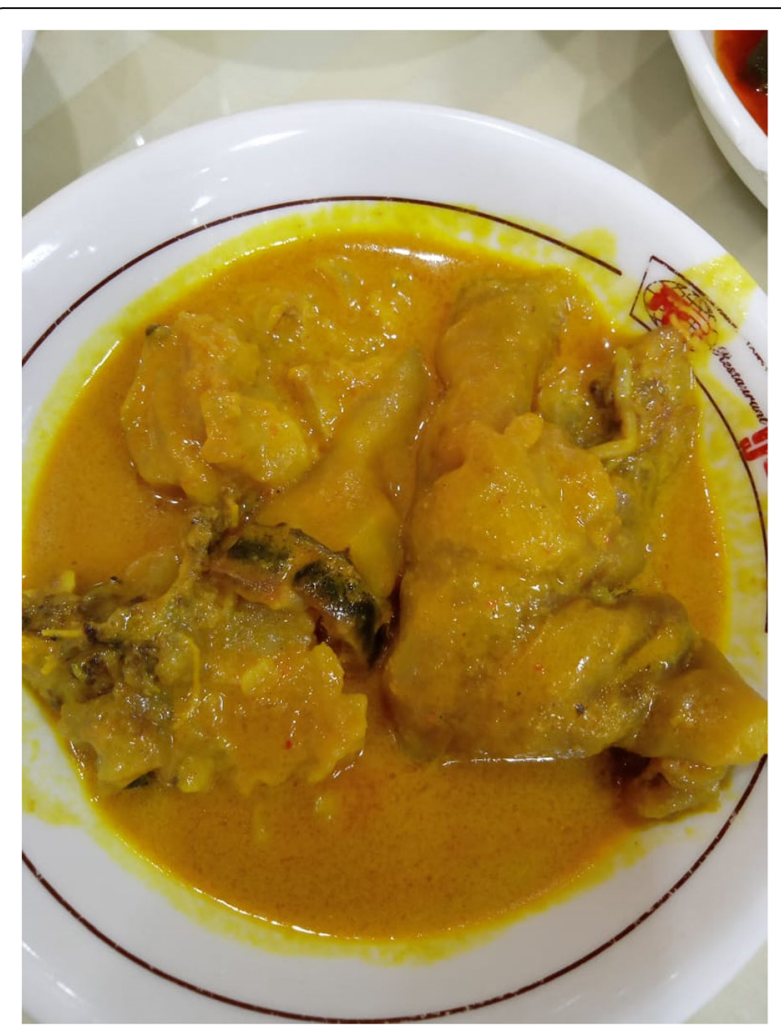

Fig. 5 Kikil Curry Spicy (Gulai Kikil). Kikil curry usually uses soft veal skin. The mixture of spices, chilies, turmeric leaves, orange leaves, and coconut milk combined with Kikil broth makes this cuisine deliciously extraordinary

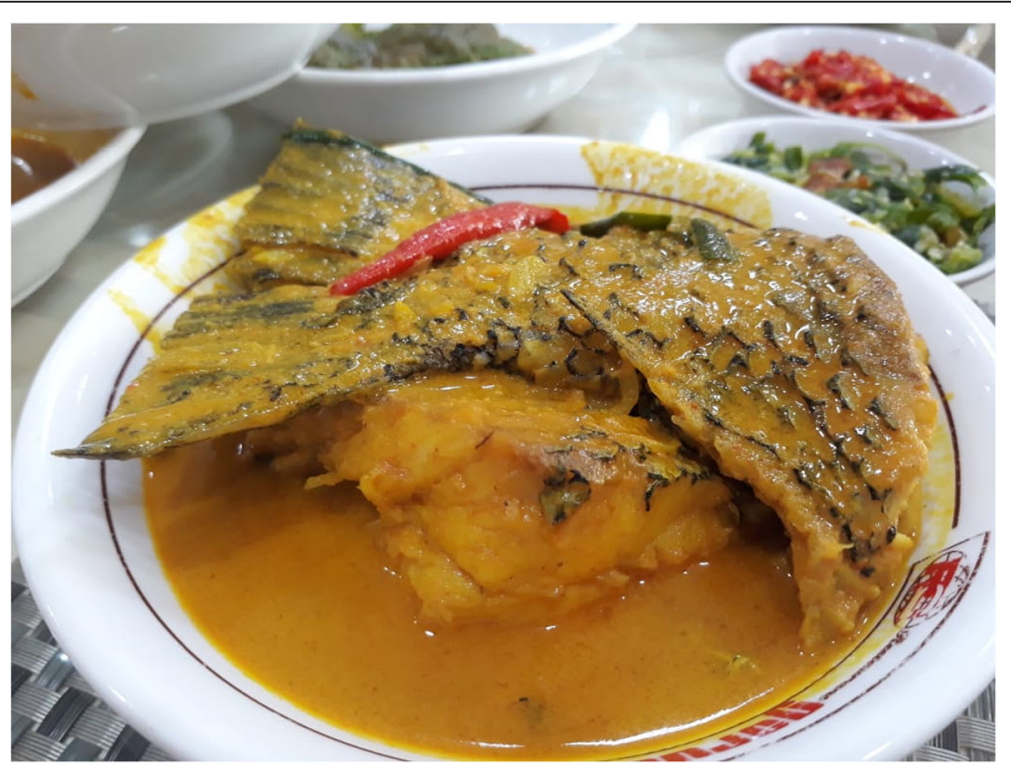

Fig. 4 Fish Curry Spicy (Gulai Ikan). Fish curry usually uses fresh snapper or other sea fish. A mixture of spices, turmeric leaves, orange leaves, kandis acid, and coconut milk makes this dish savory 


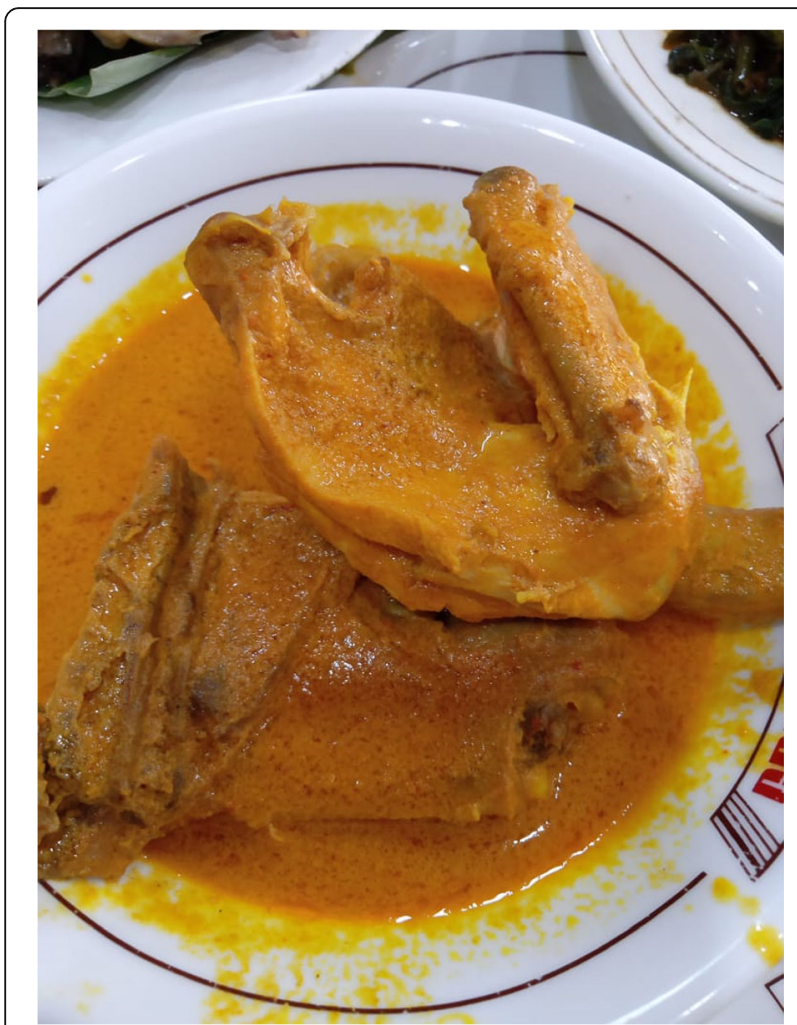

Fig. 6 Chicken Curry Spicy (Gulai Ayam), chicken curry. Chicken used is organic because it is considered healthier. The mixture of spices, chilies, turmeric leaves, orange leaves, and coconut milk are the main ingredients. Chicken broth blends with the spice mixture makes this dish savory and delicious. Source: Author Documentation, 2020. Figs. 3, 4, 5, and 6 were taken on March 5, 2020

and asam padeh meat; and savory dishes from coconut milk such as fish curry/seafood/jackfruit/long beans/ ducks, kalio meat/chicken/egg, and beef rendang/egg/ chicken. Some Minangkabau dishes are also derived from cultural acculturation as a result of cultural contact that has stopped in Minangkabau such as Arabic, Persian, Indian, Dutch, and Chinese. The culinary acculturation is a case of Minangkabau lettuce which is similar to Dutch food but has a minimal taste.

\section{Understanding food and culture identity of Minangkabau cuisine}

Traditional food is a legacy of the past as part of a tradition that serves as a marker of the identity of individuals and groups of people $[1,17]$. Culture cannot be separated from people's lives because culture is inseparable from the values, beliefs, attitudes, and practices accepted by members of community groups and then becomes a habit in daily behavior $[18,19]$.

Traditional food is said to be the regional cultural identity because each traditional food has distinct characteristics that differ from one region to another [3].

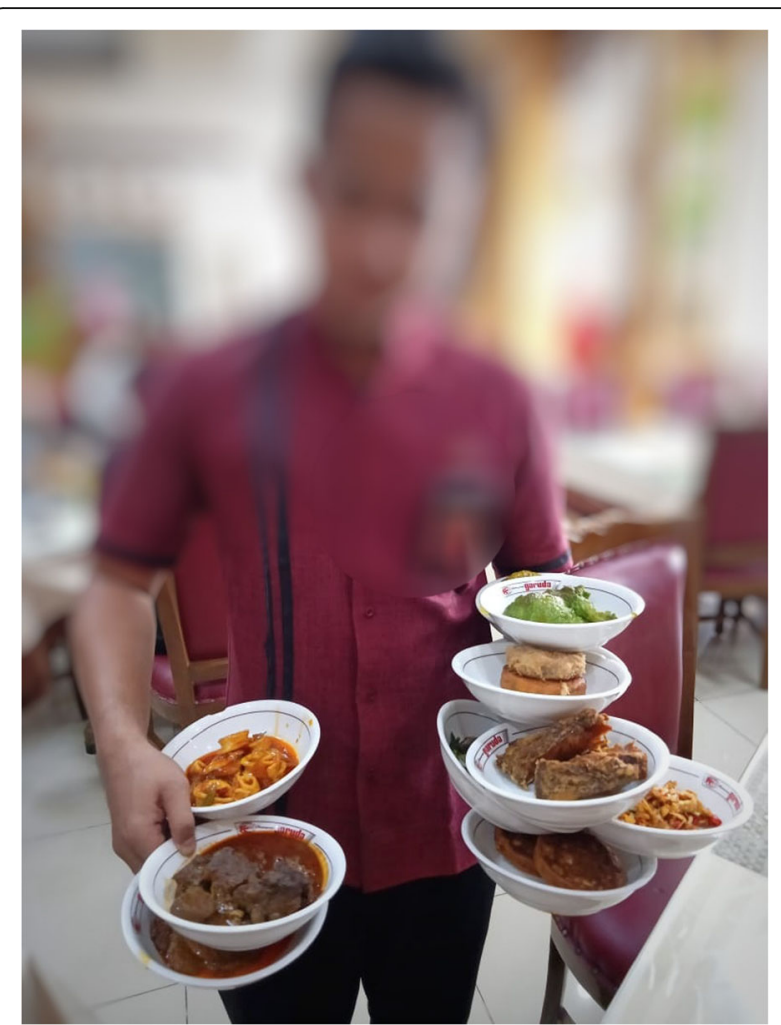

Fig. 7 Manatiang Piring. Manatiang Piring is a way a waiter brings food to be served on the table by carrying many dishes containing food at once. Source: Author Documentation, 2020, taken on March 5,2020

Traditional food is made using recipes from the past which are inherited from generation to generation prioritizing the authenticity of past tastes which then become the cultural identities of certain regions [3, 20].

The procedures for preparing food ingredients, how to cook, the composition of the amount, and variety of seasonings to the taste variations between one region and another will be different so that the type of cooking utensils used can also be different [14]. Furthermore, the authenticity of the taste of each Minangkabau cuisine becomes the cultural identity of the Minangkabau people derived from the legacy of the past recipes from the ancestors at that time including how to choose spices, processing procedures, presentation, and how to eat them.

Minangkabau cuisine consists of main dishes and cakes. The main dishes are side dishes such as meat/ chicken/fish curry, rendang, dendeng balado, chicken balado, sour padeh fish/meat, and jackfruit curry, Soto Minangkabau. Minangkabau cuisine of this main dish is made from the composition of the main spices such as ginger, turmeric, galangal, lemongrass, red chili, and coconut milk. Minang people prefer to process the spices by grinding on a special stone mat called a lado 
stone. The coconut milk used is squeezed from grated coconut meat manually by hand because the Minang people believe that processing food in this way will produce a more natural and delicious taste without the touch of modern cooking utensils.

Cake dishes like galamai are typical Minangkabau dodol made from sticky rice flour mixed with brown sugar and coconut milk. This cake takes hours to cook. Pinyaram is a typical Minangkabau sweet cake that is cooked by frying. Pinyaram is made from raw materials of rice flour mixed with liquid brown sugar or granulated sugar and then fried until cooked. This flat triangular-shaped sapik is often referred to as a typical folding semprong cake in Minangkabau. This cake is made from rice flour, granulated sugar, coconut milk, eggs, and cinnamon powder. Lamang tapai is a typical Minangkabau cake that always appears during the fasting month and other big events. As the name implies, this cake consists of lamang and tapai. Lamang is sticky rice with coconut milk and then put in young bamboo and roasted. Once cooked, the leaves are removed from the bamboo and cut into slices and then served with fermented sticky rice. There are three types of lamang tapai, namely lamang tapai original, lamang tapai banana, and lamang tapai baluo with grated coconut and brown sugar.

Delicious tastes tend to be thick from the Minangkabau cuisine is obtained because the Minang people are not stingy in providing seasoning composition to the dishes. Cooking Minangkabau cuisine requires perseverance and patience as it does in rendang cooking, which is the most popular dish of Minangkabau which is usually made from raw beef with a mixture of spices and coconut milk, even though there are also rendang available from chicken, lungs, and eggs. Rendang is a treasure of Minangkabau [26] cooked in a long way process; when referring to the original procedure, it takes up to 6 $\mathrm{h}$ to stir it with low heat cooked to dry and blackishbrown in color. Even according to the customs of the ancestors, cooking Minangkabau food is more delicious if cooking it on firewood so that it will produce an authenticity of the original taste of Minangkabau Food.

In addition to rendang, dendeng is also a dish that requires special techniques in cooking. Meat that has been seasoned with spices before cooking and must be batokok (knock) so that it becomes flat and then dried in the sun; then once it dries, it is fried over low heat with a lot of oil until submerged. Minangkabau cuisine does not recognize food coloring, preservatives, and flavor enhancements because alama spices such as ginger, turmeric, galangal, lemongrass, onion, garlic, and coconut give strength to the taste and color of food.

Food culture in the way to eating Minang people is called bajamba or barapak eating. This tradition has existed since the seventh century originating from Koto Gadang Agam, West Sumatra, which is a common eating activity carried out on celebration of religious days, weddings, and traditional ceremonies. Bajamba eating is seen as a form of application of "Adaik Basandi Syarak, Syarak Basandi Kitabullah" where the Minang custom originates from Islam so that this tradition is carried out to follow the sunnah of the Prophet. The participants will sit together on the floor in a circular position with rice and side dishes placed on a tray. The stipulations on the procedure for bajamba eating are that participants must not take food served in front of them if there are older people who have not taken the food. The tradition of eating bajamba has a philosophy of life that is to train oneself to share life in togetherness regardless of each other's social status and respect for older people.

\section{Enterprise cultural heritage as sustainable competitive advantage in Minangkabau cuisine restaurant}

Enterprise cultural heritage $(\mathrm{ECH})$ is a combination of history and company products that originate from potential resources having unique, innovative, and differentiated products and services, recognized by the company [27]. Through the enterprise cultural heritage, the company can identify the inherited values inherent in the business. Branding and marketing exploitation is recognized as an important element of a company's cultural heritage $[25,28]$ that can be carried out and preserved which then provides traditional appeal and cultural symbols that distinguish the company from competitors $[8$, 29]. In the context of Minangkabau restaurant or Padang restaurant generally known, Minangkabau cuisine is already familiar, often found in various Minangkabau restaurants in almost all regions of Indonesia and even abroad. Restaurants have been legendary since a century ago, but in the past, the form of Minangkabau restaurants shows stand like a small shop selling kapau rice typical of Bukittinggi, Minangkabau. Kapau rice is mixed rice that is fertilized with jackfruit curry vegetables along with side dishes typical of Padang dishes such as chicken and rendang. The sustainability of the Minangkabau restaurant business from the beginning until now can be seen from its existence which is still able to compete sustainably among the many emerging modern foods in this globalization era.

Minangkabau restaurant is a business company that has history and knowledge as a strength that is the company's cultural heritage. According to the previous research $[8,25,30]$, it is said that enterprise cultural heritage is a source of a sustainable competitive advantage by prioritizing past history and the knowledge has to be more valuable and unique than their competitors. Homogeneity in the era of globalization breeds 
consumer tastes so that the authenticity and past traditions of culinary heritage are highly valued by consumers in the current era because they can reminisce about their past memories about food [10, 23, 24, 27]. Choosing to consume traditional cuisine is not just a choice of one's lifestyle but gives a symbolic meaning to one's cultural identity [31,32] which further binds a local identity and local specialization [10]. Culinary heritage comes from awareness of the attention of each individual in committed to maintaining value preservation of culinary heritage that serves as a cultural symbol identity expresses people's hearts [33]. Minangkabau restaurant or Padang restaurant in its development does not mean not doing innovation. Innovations made as a step in marketing strategy to achieve sustainable competitive advantage by placing food culture as a strong identity of Minangkabau cuisine. The tradition of maintaining the authenticity of the knowledge of concocting spices according to recipes of ancestral heritage is still maintained until now. Minangkabau cuisine always uses natural and fresh spices which are processed directly without involving modern production machinery. The thick, savory, and spicy taste is an authentic taste of Minangkabau cuisine. Mixing and smoothing the spices in Minangkabau cuisine prefer using a lado stone mill rather than using a blender machine. This is believed to bring out a more natural and authentic taste.

The past role of the Minangkabau cuisine restaurant provides a resource asset that can be exploited for the sustainability of this business. This is in line with the opinion of [8] the long history of the past for the company will be a valuable asset that can be exploited. Past traditions related to business become concepts that will include different views compared to competitors such as the concept of cultural heritage [34], a corporate heritage brand specifically invested which is a blend of continuity of identity, change of identity and invested with past time identity, present and future that will provide a collective memory of a group of people [30, 33, 35, 36], and cultural identity and heritage attractions have occupied a prominent role in managing the company's marketing strategy to achieve a wider social environment and tourism [31, 33, 37]. Furthermore, according to [38] the cultural heritage, this does not include all cultural traditions and inheritance production has an ambivalent role because local culture and identity have been the basis for social and economic growth.

Company resources as a corporate cultural heritage consist of categories namely tangible and intangible assets [39]. Tangible assets such as buildings, machine tools of production, and products that have historical value for the company are seen from a historical commercial point of view, whereas intangible assets are social habits that are commonly practiced and verbally distributed among people in the company such as company owners, employees, suppliers, and customers which include the way services are provided, recipe knowledge and product processing methods, and history related to the overall evolution of the company's history [8].

In the context of the Minangkabau food restaurant, it shows that modern market competition is getting tougher, but the existence of the Minangkabau food restaurant is sustaining. The cultural heritage values of the enterprise owned by the Minangkabau restaurant, in general, are very specific in terms of their ability to prioritize the authenticity of the Minangkabau cuisine food culture itself. Minangkabau cuisine in terms of its development continues to innovate, but not from the application of technology that destroys the food culture of the identity of the Minangkabau cuisine; it can be noted from their procedures in maintaining the food culture of the Minangkabau cuisine, starting from the processing procedures, determining the amount, and variety of seasoning composition up to the presentation. The distinctive feature of serving the Minangkabau restaurant is by presenting its food on a large bowl arranged stratified in a glass display case.

Historically, the past during the Dutch colonial era, the owners of Padang rice stalls liked to give the poor the side dishes by way of being wrapped. This is the initial story among the connoisseurs of Padang cuisine that Padang rice is wrapped in a portion of rice more than eating in a place. Poor people who buy wrapped will be given a double portion to be able to eat together with their families at home because Padang food in rice stalls used to be enjoyed only by the Dutch Caucasian colonizers which until now we will find the same thing.

Presentation of curry pan and rice tray is placed slightly downward to make it easier for the seller to reach. Minangkabau restaurant servants are dominated by men who are unique in serving dishes. They will bring a number of dishes at the same time with stratified or overlapping with only two sides or one hand; this is an interesting attraction for the visitors. Then all the small plates containing these dishes are served to guests. The guest can take the food he likes and only pays for the food he takes. When the meal is finished, the waiter will check what dishes the guest has eaten.

Furthermore, this unique way of serving will not be found from most other restaurants. Generally, if a guest enters, he will be presented with a menu and will order food from the menu. This attraction is an example of a service that has a cultural heritage background from the enterprise cultural heritage of the Minangkabau restaurant. The value of uniqueness, rare resources, inimitated, and non-substitute owned by Minangkabau cuisine restaurant resources displays a strong heterogeneity compared to its competitors. This is in line with [36, 39-41] 
that a company can compete with sustainable competitive advantage if company's resources have value, rare resources, inimitable, and non-substitute which make these resources not easily move to competitors. Inheritance assets at companies such as the Minangkabau restaurant can be used to compete in value propositions and attract customers based on the added value to the product.

\section{Conclusion}

The review and discussion of the cultural heritage of the Minangkabau cuisine enterprise show that Minangkabau cuisine has a strong past history and food culture as the authenticity of the culture of Minangkabau people's identity in the selection of foods they consume. The company's resources are made up of past history and unique, rare, inimitable, and non-substitutional knowledge as assets of corporate to achieve sustainable competitive advantage in the era of the global market. This study is expected to serve as an initial contribution to focus more on discussing the culinary heritage of wealth in Indonesia, especially by not ignoring the enterprise cultural heritage as a source of achieving sustainable competitive advantage.

\section{Acknowledgements}

Thank you for Mrs Delmira Syafrini and Mrs Muhyiatul Fadilah who have been helping the authors in the process of this article by contributing important information about Minangkabau cuisine culture heritage.

\section{Author's contributions}

The author reads, provides knowledge about history, food culture, geographical, ethnic food, and enterprise cultural heritage of Minangkabau cuisine, and approved the final manuscript.

\section{Author's information}

Annisa Mardatillah is a senior lecturer in Business Administration, Universitas Islam Riau, Riau Province, Indonesia. She is currently a Doctor of Philosophy of Business Administration in Business Administration at Universitas Padjadjaran, Bandung, Indonesia. Her research interests are in the field of strategic management, particularly in the sustainable competitive advantage of ethnic food, business administration, and marketing

\section{Funding}

This study did not receive the support of certain costs from the funding agency in the public, commercial, or non-profit sector.

\section{Availability of data and materials}

All datasets have been presented in this paper.

\section{Competing interests}

The author declares that she has no competing interests.

Received: 14 November 2019 Accepted: 31 July 2020

Published online: 22 September 2020

\section{References}

1. Jordana J. Traditional foods: challenges facing the European food industry. Food Res Int. 2000:33:147-52

2. Pieniak Z, Verbeke W, Vanhonacker F, Guerrero L, Hersleth M. Association between traditional food consumption and motives for food choice in six European countries. Appetite. 2009;53(1):101-8.

3. Guerrero $L$, et al. Perception of traditional food products in six European regions using free word association. Food Qual Prefer. 2009;21(2):225-33.
4. Chambers S, Lobb A, Butler L, Harvey K, Bruce Traill W. Local, national and imported foods: a qualitative study. Appetite. 2007:49(1):208-13.

5. Aykan B. The politics of intangible heritage and food fights in Western Asia. Int J Herit Stud. 2016:22(10):799-810.

6. Elizabeth $\mathrm{G}$. The role of local food in destination marketing: a South African situational analysis. J Travel Tour Mark. 2006;14(3):97-112.

7. Henderson JC. Heritage attractions and tourism development in Asia : a comparative study of Hongkong and Singapore. Int J Tour Res. 2002;4: 337-44

8. Aaltonen. Enterprise cultural heritage: the source for sustainable competitive advantage and survival for food sector SMEs. Int J Entrep Innov. 2015;16(2): 73-83.

9. Gellynck X, Banterle A, Ku B. Market orientation and marketing management of traditional food producers in the EU. 2012;114(4):481-99.

10. Autio M, Collins R, Wahlen S, Anttila M. Consuming nostalgia? The appreciation of authenticity in local food production. Int J Consum Stud. 2013:37(5):564-8.

11. Djamaris E. Tambo Minangkabau. Jakarta: Balai Pustaka, Jakarta; 1991.

12. Wijaya S. Indonesian food culture mapping: a starter contribution to promote Indonesian culinary tourism. J Ethn. Foods. 2019;6(9):1-10.

13. Wang YL. Study on sustainable development of Qinhuai culinary culture. Jiangsu Condiment Subsid Food. 2013;135:42-4.

14. Kittler MN, Sucher PG, Nelms KP. Food \& culture. Boston: Cengange. Learning. 2012.

15. Tarr A. Food and culture: from local relationality to global responsibility. J Dialogue Cult. 2016;3(1):52-62

16. R. Evers, Hans Dieter; Korff, Southeast Asian urbanism. LIT Verlag Münster: Ed.2nd., 2000.

17. Lipoeto NI, Agus Z, Oenzil F, Masrul M, Wattanapenpaiboon N, Wahlqvist ML. Contemporary minangkabau food culture in West Sumatra, Indonesia. Asia Pac J Clin Nutr. 2001;10(1):10-6.

18. Kwon DY What is ethnic food? J Ethnobiol. 2015:2:6181.

19. Klopfer L. Padang restaurants: creating 'ethnic' cuisine in Indonesia. Food Foodways. 1993:5(3):293-304

20. Asnan G. Dunia Maritim Pantai Barat Sumatra. Yogyakarta: Penerbit Ombak; 2007

21. Utomo E. Bambang Budi; Karim, Mulyawan; Sundari, Treasures of Sumatra. Jakarta: Direktorat Jenderal Kebudayaan; 2009.

22. Scarpato RR, Daniele. New global cuisine: tourism, authenticity and sense of place in postmodern gastronomy. In: Hall CM, Sharpley L, Mitchell R, Maconis N, Cambourne B, editors. Food Tourism around the World: Development. Oxford: Butterworth-Heinemann; 2003. Management and Markets.

23. Outka E. Consuming traditions - modernity, modernism, and the commodified authentic. Oxford: Oxford University Press; 2009.

24. Halweil B. The case for local food in a global market. Washington DC: Worldwatch Institute; 2002

25. Santos. Heritage branding orientation: the case of Ach. Brito and the dynamics between corporate and product heritage brands. 2016:23(1):67-88.

26. Nurmu M, Wangrimen GH, Reinalta R, Leonardi K. Rendang: the treasure of Minangkabau. 2017:4(4):232-5.

27. Aaltonen S, de Tommaso S, lelpa D, Heinze G, Kalantaridis A, Vasilieva C, Zygiaris E. Power of the past and SME competitiveness: a European study. Entrepreneurship: Bridging global boundaries. Cincinnati: International Council for Small Business (ICSB); 2010.

28. Beverland $M$. The real thing: branding authenticity in the luxury wine trade. 2006;59:251-8

29. Balmer JMT. Corporate heritage identities, corporate heritage brands and the multiple heritage identities of the British Monarchy. 2011;45(9):1380-98.

30. E. V. Counihan C, Food and culture: a reader., 2nd ed. New York: Routledge Taylor \& Francis Group, 2008

31. Warde A. Consumption, food and taste. London: Sage Publications; 1997.

32. Gilmore BJ. J.H. and Pine, What consumers really want: authenticity. Boston: Harvard Business School Press; 2007.

33. Cheung $\mathrm{SCH}$. From foodways to intangible heritage: a case study of Chinese culinary resource, retail and recipe in Hong Kong. Int J Herit Stud. 2013;19(4):353-64

34. Craith N. Cultural heritages as reflexive traditions: Palgrave Macmillan; 2006.

35. Zeng G, Zhao Y, Sun S. Sustainable development mechanism of food culture's translocal production based on authenticity. Sustainability. 2014;6: 7030-47. 
36. Marlene Fiol C. Managing culture as a competitive resource: an identitybased view of sustainable competitive advantage. J Manag. 1991;17:191

37. Balmer B. Explicating corporate heritage corporate pdf. J Brand Manag. 2015;22(5/6):364-84

38. Kockel U. Reflexive traditions and heritage production: Palgrave Macmillan; 2007.

39. Swensen $\mathrm{G}$, Jerpåsen $\mathrm{GB}$, Sæter $\mathrm{O}$. Capturing the intangible and tangible aspects of heritage: personal versus official perspectives in cultural heritage management. Landsc Res. 2013;38(2):203-21.

40. Barney J. Barney 1991.pdf, Firm resources and sustained competitive advantage. J Manag. 1991;17(1):99-120

41. Barney JB. Resource-based theories of competitive advantage: a ten-year retrospective on the resource-based view. J Manag. 2001;27(6):643-50.

\section{Publisher's Note}

Springer Nature remains neutral with regard to jurisdictional claims in published maps and institutional affiliations.

Ready to submit your research? Choose BMC and benefit from:

- fast, convenient online submission

- thorough peer review by experienced researchers in your field

- rapid publication on acceptance

- support for research data, including large and complex data types

- gold Open Access which fosters wider collaboration and increased citations

- maximum visibility for your research: over $100 \mathrm{M}$ website views per year

At BMC, research is always in progress.

Learn more biomedcentral.com/submissions 